\title{
HOW COULD WARUNG TEGAL FRANCHISE'S SYSTEM BECOME INTERESTING?
}

\author{
Endah WIDATI* and Annisa MADANIAH \\ Universitas Indraprasta PGRI, Indonesia \\ *endahwidati82@gmail.com
}

\begin{abstract}
Since the first case of covid19 confirmed at Depok and the covid19 patient increased, government through its regulation no. 21 year 2020 about Indonesian Large-Scale Social Restriction (LSSR) have been applied in various level up to implementation of restrictions on community activities lately. To survive, many of them try to start another business, culinary business becomes a favorite business to choose. Start from appetizers up to dessert. The other choose is main course. Currently home-made food become famous business to run. Food is basic need, everyone needs foods, traditional or modification. Warung Tegal (Warteg), one's of famous traditional food stalls in Indonesia. Cheap, big portion of food, home-made and variety of menu make Warteg become blue-collar worker and lower income favorite place to eat. this study aims to know the benefit and advantage develop warteg as business choices, either self-force or franchise. This research is a qualitative research. Using one sample of Indonesian traditional food stall, which established more than 30 years and compared it with the current warteg franchise system. Interview and observation become collecting techniques in gathering the data. The result found that Warteg offer more than 26 menu every day, which give average PVCM 615,19\% totally including coverage minus PVCM such as crispy tempeh, beside stable income and profit give interesting point of why people chose start Warteg business.
\end{abstract}

Keywords: Warteg, Competitive Advantage, Marketing, Profitable Analysis, Indonesian Traditional Food Stalls

\section{BACKGROUND}

Since the first case of covid19 confirmed at Depok and the covid19 patient increased, government through its regulation no. 21 year 2020 about Indonesian LargeScale Social Restriction (LSSR) have been applied in various level up to implementation of restrictions on community activities lately. Many effects caused by regulation implementation primary business and worker in education, tourism and entertainment industry, which are suddenly have to stop all the program activities. More than 150.000 people lost their job (tirto.id, 2020). To survive, many of them try to start another business, culinary business becomes a favorite business to choose. Start from appetizers up to dessert. The other choose is main course. Currently home-made food become famous business to run. Food is basic need, everyone needs foods, traditional or modification.

Warung Tegal (Warteg), one's of famous traditional food stalls in Indonesia. Its existences established since in mid-1950's (Tampubolon, 2020) up to mid-1970's (Meilasari-Sugiana, Tri \& Mirsa, 2019) when Jakarta on development process. Most of people out of Jakarta, mostly Javanese ethnic tried their lucky to get an income as bluecollar worker in infrastructure area. Shortly, to fulfill their needs, their wife tried to sell any ready-to-eat home food in project area. Warteg is a form of micro-business related to the nature of regionalism (Kadarisman, 2019) and ethnicity (Tampubolon, 2020). Cheap, big portion of food, home-made and variety of menu make Warteg become blue-collar worker and lower income favorite place to eat. In the first time, most warteg are managed by people from Sidapurna village and Sidakaton Village in Tegal City, Middle Java, Indonesia (Meilasari-Sugiana, Tri \& Mirsa, 2019). Usually, Warteg are manage using shifting system (in family member which have same ancestor root). The shifting system usually in between 3 or 6 months, while others member which not on in shift usually farming in their homeland. Warteg owners' in Jakarta usually join in warung tegal cooperation, known as Koperasi Warung Tegal (Kowarteg) (Kadarisman, 2019).

Nowadays, if we look around in Jakarta and few regions such as Tangerang, Bogor, Bekasi and Depok, either in business area or residence area, we can find warteg easily. Before the pandemic, there are around 50,000 warteg exist in Jakarta and serve almost 7 million people, including worker and Jakarta citizen. The interesting trend is currently warteg not only identically with low income people but also middle income. Designed with new standard as family restaurant, few brands of warteg start to expand their business using franchise system. As mention, many businesses use franchise system as quick way to expand their business. In Indonesia, recently franchise not only applied by middle up business but also micro-business such as Warteg, i.e. Warteg Kharisma Bahari Group, inadvertence as effect of unorganized their second and third branch which managed by the employee, the owner started to offer other family members and friends who want to open culinary business but does not have any capital. WKB also launched other brands under their group. Apart of Kharisma Bahari, Wowteg from Sour Sally also offer the franchise system. Differ from the previous research, this study aims to know the benefit and advantage develop warteg as business choices, either selfforce or franchise.

Franchise become one of popular ways to expand the business and mostly run by middle up business. It started in early 1880 's, when Isaac M Singer wanted to find wider distribution channels and realize that he needs to teach them how to use and maintain it (franchoice.com, 2021). When the franchise systems are growth and mature, it need for legalize the system and give the followed customers protection. In 1960, the International Franchise Association (IFA) was established in aim to provide help and guidance to entire industry (franchoice.com, 2021). 
In a word, franchising means license. Seid and Mazero (2017) defines franchise as a system that delivers quality brand of a product throughout independent network possessed and operated by individual or group. There are 3 types of franchising (Seid and Mazero, 2017) such as: traditional or product-distribution franchising, businessformat franchising and social francising. The advantages of start a business using franchise (Ramadhan, 2010) are becoming business owner, the easy way to start business, knowing easily as the effect of popular brand, increasing opportunity of successful probability, help the business owner to offer consistent quality of product and service, getting a sustainable support from the franchisor. In the other side, the disadvantages of franchising are business is not completely independent, additional cost and limited by time.

Likes other business, Franchise also need marketing strategy. Marketing strategy defines as process of marketdriven strategies improvement considering environment and human needs change to offer superior customer value (Cravens and Pierce, 2012). Cravens and Pierce (2012) four phases of process in marketing strategy such as defines market, segments and customer value, designing market-driven strategies, market program development, implementing and managing market-driven strategies. Marketing strategy not only as a part of functional strategy but also a business strategy (Kotler and Keller, 2016). In order to develop market-driven program, company uses marketing mix that consist of product, price, place, promotion (McCarthy, 1960 in Kotler and Keller, 20216), process, physical evidence, people (Booms and Bitner, 1980), productivity and quality (Writz and Lovelock, 2016). Futhermore to gain the competition, a business should have a sustainable competitive advantage. Competitive advantage defines as ability of a business resource to create cost relative position and create differentiation (Porter, 1998)

\section{METHODS}

This research is a qualitative research. Using one sample of Indonesian traditional food stall, which established more than 30 years and compared it with the current warteg franchise system. Interview and observation become collecting techniques in gathering the data. This research also used secondary data from media and website. This research uses descriptive analysis (Sugiyono, 2018) and profitability analysis (Tjiptono and Chandra, 2018) to measure the profit of each menu offer by research object.

\section{RESULTS AND DISCUSSION}

Nowadays, to start warteg business people can choice whether open with self-force or franchise system. People can arrange the initial investment if they decide to open with self-force. Whereas, people need to prepare amount of money if they choice to use franchise system.
Few of warteg business offer franchise systems are such as Warung Jakarta (WarJak), Kharisma Bahari Group (KBG), WowTeg and Warteg Putra Bahari.

First, Warung Jakarta (WarJak). Established in 2017, currently WarJak have more than 50 partners. In order to join WarJak partnership potential store owner should prepare at least Rp. 10,5 million (USD 729,03) to get business license of Warung (WarJak), the same as warteg concept. Warjak gives its partner the packages of equipment, such as: display cases, dining tables, dining benches, plates, spoons, vegetable spoons, rice paper, etc., and supplies of varies foods that are ready and just served. WarJak provide 60 menus everyday which can be picked up in nearest pickup point with the partner outlet. Before signed the agreement, the potential partner can try all varies menu provided. For the outlet location, WarJak do not give any special condition, the potential partner can choose whether will open it in front of the house or in a store bulilding. In determine the selling price, WarJak Company give any freedom to its partner to determine it. Besides that, WarJak management also give accompaniment for its partnership to ensure they can run and survive the business.

Second, Kharisma Bahari Group (WKB). Established by Mr. Sayudi in 1996, the franchise system started applied after the third branch of Warteg Modal Mertua (previous name of Kharisma Bahari Group) experienced loss and under messy management. Start offer the franchise system to its friends or family who want to open warteg business with profit sharing, which is 50\% - 50\%. Currently WKB have more than hundred partners around Jabodetabek. Kharisma Bahari Group offer various packages of franchise system such as Small Warteg Package, Medium Warteg Package, Great Warteg Package, Super Warteg Package. There are 4 brands under WKB besides the brand itself. Those brands are mamoka bahari, subsidi bahari, selaras bahari and sarirasa bahari. The franchise price start at $\mathrm{Rp}$. 110 million up to Rp. 150 million (around USD 7,637.43 to USD 10,414.68). This amount is brand price of Warteg Kharisma Bahari only. The system offer is buy-break system. With the amount spent, Kharisma Bahari provide renovation activities plan, cooking utensils, furniture, storefronts, employee and the cook. WKB's sharing system is 50:50 from net profit. This allocation is for the cook and not WKB management. Using its motto "Mewartegkan Jabodetabek" WKB also offer credit system 50\% in advance for interest potential store owner and installment for the rest amount. WKB offer the full management for the partner so they no need to worry if they did not know about the management. WKB also give accompaniment for its potential partner as wishes that the business will survive and run smoothly. As the franchise system professional, WKB management also ensure that the location selected already fulfill the requirement of human traffic and not closed enough with other outlets. According to the partner in normal time (not in pandemic) in weekday, partner can 
get sales revenue up to Rp. 7,000,000.- (USD486,02 ) while in weekend average income up to Rp. 4,000,000 (USD 277,72) per day.

Third, WowTeg from Sour Sally. Carry out the modern and hygienic warteg Wowteg (warteg yang wow) start operate and offer franchise system. Wowteg from Sour Sally offer two categories of places that potential store owners can choose. The first is Canteen Wowteg with a minimum area of 12 square meters and Street Level Wowteg with a minimum area of 30 square meters. The initial investment if potential partner wants to buy Wowteg license is around Rp. 200,000,000.(USD 13,886.24). Based on profit simulation, the gross profit is Rp. 39,930,000 (USD 2,772.32) for the Canteen Wowteg type and Rp. 61,875,000 (USD 4,296.05) for the Street Level Wowteg type per month. The net profit per month can reach Rp 15,474,000 (USD 1,074.38) for the Canteen Wowteg type and Rp 22,025,000 (USD 1,529.22) for the Street Level Wowteg type. Different with other franchise system, Wowteg use modern interior concept in considering the visitor comfort level. Starting from airconditioned rooms, non-smoking, to food displays and hygienic utensils. Wowteg use central kitchen concept. In this central kitchen food is cooked by professional chefs, then delivered to all outlets. The central kitchen concept ensures the store free of cooking pollution. Wowteg ensure that the central kitchen possess HACCP certificate.

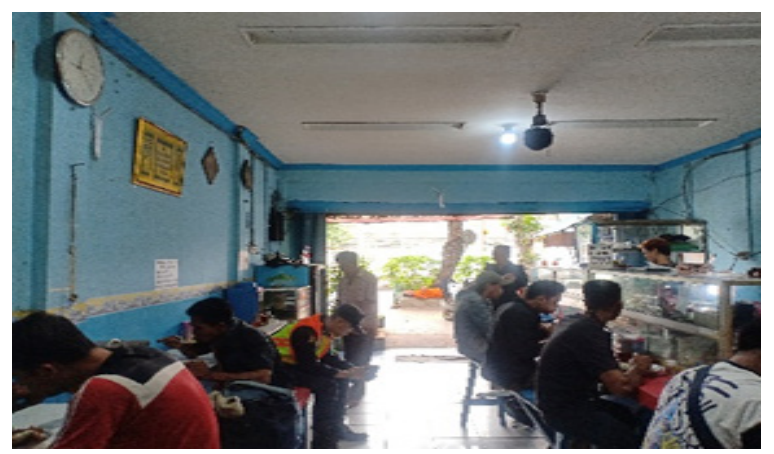

Figure 1. Condition of traditional warteg

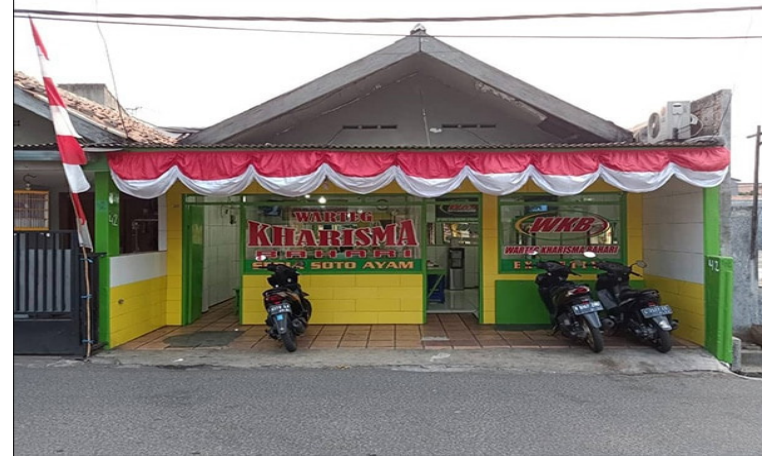

Figure 2. outdoors appearance of WBK

The last, Warteg Putra Bahari. The others Warteg business franchise system established by Mr. Anang, Mr. Dimas, and Mr. Darman, in 2014. Currently more than 120 outlets in Jabodetabek. Potential investor or partner need to invest around Rp. 140,000,000.- (USD 9,720.37) to get warteg putra bahari license.
According to the previous explanation, we can analyze that initial investment for each franchise system over various depends on what you want to get. i.e. Wowteg WKB and Warteg Putra Bahari offer such of amount because potential investor needs to prepare few of requirement tools and equipment including interior and exterior design of outlets. In the other hand, WarJak only require a small space to open the business so the initial investment is not so high like others sample object. Based on product and price, those wartegs offer the similar menu which is home-made food, traditional Indonesia culinary, offer more than 20 menus, affordable price (based on the company) start Rp. 1.000,-(USD 0,069) up to Rp. 30,000,(USD2,08). From the place or marketing channel, those business not only serve dine in but also start to use ride hailing service to keep survive in the pandemic. Few of them also start to optimize the useful of social media such as Instagram and Facebook.

In strategic marketing point of views those wartegs business have each competitive advantage. First, target market. WarJak, WBK and Putra Bahari set their target market to all segment including low-middle economy, while WowTeg tend to set the target market for middle-up economy. Furthermore, those warteg, either the traditional or modern warteg try to position their business as clean and modern warteg (see figure 5, 6 dan 7). They try to change customer perception about warteg "look a like" in the past. The next point is branding. Brand defines as a set association related to product's name, mark and symbol (Calkins, 2019). While American Marketing Association in Keller and Swaminathan (2020) defines a brand as a name, term, sign, symbol or design or a combination of them intended to identify the goods and services of one seller a group or group of sellers and to differentiate them from those of a competition. Thus, branding is a consumers' mental process create product knowledge and perception in order to help them make a decision (Keller and Swaminathan, 2020).

As the "real warteg" WKB and Putra Bahari try to keep the special features of warteg such as always 2 doors, use big glass of windows and bright color, offer more than 20 menus of Javanese traditional foods. Unfortunately, the similarity color choices could confuse the consumer. The use of green light, yellow and orange create many people think or assume that Putra Bahari and WKB is the same company. It is not consumer fault, but as a franchise company make different identity is important to do. There no specific symbol or design can be differentiate from both of them. Only the world "Bahari" as a sign that their warung is identically with "Tegal people". the other competitive advantage is the familiar food taste for every menu and people already familiar with warteg whatever its format. As basic need provider, warteg become an interesting business cause every day every human need food, with the strategic location and use all digital tools such as ride hailing service and delivery service, warteg become a profitable business in every economic condition. 
In order to compare all those warteg frasnchise, this research compare the income calculation with private warteg possessed by Tegal people. The object research is an Indonesian traditional food stalls, located in Rawabunga, Jatinegara. The business has been established more than 30 years. The business growth in line with urbanization growth. They offer 24 menu of foods and 2 types of drink. The prices between IDR 1,000. - (USD 0,069) up to IDR 8,000. - (USD 0,55) for each item. For the food packages, price starts at IDR 6,000, - (USD 0,42) up to IDR. 29,000.-. (USD $2,01)$. As micro business, the research object is managed by the main family member and only apply shifting system on daily operational system with 3 employee supported. It open 24 hours a day, 7 days a week except Moslem Holiday. At the beginning, the owner starts the business with little amount of money, while the place was rent. Currently, the income up to IDR 5,000,000. - (USD346,27) per day in normal situation, while in pandemic situation the income only quarter of usual. To survive in the business, the owner keeps taste of its food and depends on words-of-marketing effect. To facilitate dine in, the owner rent the $2^{\text {nd }}$ story simple building, it is $62,5 \mathrm{~m}^{2}$ each floor, Rp. 70 million (USD 4,847.75) costly in a year.

Based on observation result, the sustainable competitive advantages possessed by the object are quality of food, customers satisfaction, capital availability, innovation effectiveness, price setting effectiveness, dedicated and reliable employee, business reputation and market share. While for the leadership innovation, they only possess parity competitive advantage. It can be understandable since the owner are not educated person. Others weakness of the object is geography coverage, production effectiveness and incomplete facilities as dine in restaurant and promotion effectiveness. As the result of resource or capability, table 1 show the item of food packaged, drinks sold in the last six years and table 2 shows the total income.

Table 1. Sales Quantity

\begin{tabular}{ccccc}
\hline Year & $\begin{array}{c}\text { Food } \\
\text { Packages }\end{array}$ & $\begin{array}{c}\text { Sweet ice } \\
\text { tea }\end{array}$ & $\begin{array}{c}\text { Orange } \\
\text { Juice }\end{array}$ & $\begin{array}{c}\text { Total } \\
\text { Sales }\end{array}$ \\
\hline 2015 & 4,120 & 2,480 & 1,648 & 8,248 \\
2016 & 2,640 & 1,584 & 1,056 & 5,280 \\
2017 & 2,512 & 1,512 & 1,000 & 5,024 \\
2018 & 2,536 & 1,520 & 1,016 & 5,072 \\
2019 & 2,616 & 1,568 & 1,048 & 5,232 \\
2020 & 8,352 & 5,554 & 3,382 & 17,288 \\
\hline Total & 22,776 & 14,218 & 9,150 & 46,144 \\
\hline
\end{tabular}

Table 2. Sales Revenue In Rupiah

\begin{tabular}{crccc}
\hline Year & Food Packages & $\begin{array}{c}\text { Sweet Ice } \\
\text { Tea }\end{array}$ & $\begin{array}{c}\text { Orange } \\
\text { Juice }\end{array}$ & Total Sales \\
\hline 2015 & $399,640,000$ & $7,440,000$ & $8,240,000$ & $415,320,000$ \\
2016 & $332,640,000$ & $4,752,000$ & $5,280,000$ & $342,672,000$ \\
2017 & $316,512,000$ & $4,536,000$ & $5,000,000$ & $326,048,000$ \\
2018 & $319,536,000$ & $4,560,000$ & $5,080,000$ & $329,176,000$ \\
2019 & $329,616,000$ & $4,704,000$ & $5,240,000$ & $339,560,000$ \\
2020 & $105,235,800$ & $16,662,000$ & $1,910,000$ & $1,085,930,000$ \\
\hline Total & $1,803,179,800$ & $42,654,000$ & $45,750,000$ & $1,752,776,000$ \\
\hline
\end{tabular}

According to table 1 and 2, the sales of research object decreased. These numbers are affected by unfocus management in organize the business because of had not found fixed business place yet in 2015 - 2016 . Furthermore, in 2016 - 2017, the decrease occurs because of the store was often closed, this occurs because the owner had often to go back to her hometown. In 2020, 2 months (Jan - Feb) before the pandemic occurs, the sales volume still stable average 1,754 food packages and drinks. However, when the pandemic occurs and largescale social restrictions applied for the first time, sales drop to 824 food packages in average. As business which offer human basic need, after 2 months (Mar - Apr) the business can return to normal condition after making some adjustments in process and also dine in policies.

As middle-low restaurant, Warteg has to consider 2 types of cost such as fixed and variable cost. the research object's fixed cost consists of building rent, employee salary, water and electricity, totally Rp. 137,200,000,(USD 9501,2) per year. The variables costs are raw material and supporting material which number varies. Profit calculation (table 3 ) shows average profit in 5 years (2016 - 2019, 2015 did not calculate because there is not available data for both cost) Rp. 32,553,482,- (USD $2,254.44)$. Even though the business can adjust the external business environment, they still experience loss in 2020 around 14 million rupiahs or equal to USD 972,04

Table 3. Business Profit

\begin{tabular}{crccc}
\hline Year & Sales Revenue & Variable Cost & Fixed Cost & Profit \\
\hline 2015 & 415.320 .000 & N/A & N/A & N/A \\
2016 & 342.672 .000 & 247.365 .360 & 137.200 .000 & 41.893 .360 \\
2017 & 326.048 .000 & 235.371 .744 & 137.200 .000 & 46.523 .744 \\
2018 & 329.176 .000 & 237.620 .712 & 137.200 .000 & 45.644 .712 \\
2019 & 339.560 .000 & 245.116 .632 & 137.200 .000 & 42.756 .632 \\
2020 & $1.085 .930,000$ & 783.427 .924 & 137.200 .000 & -14.051 .038 \\
\hline Total & 1.752 .776 .000 & 1.357 .188 .410 & 686.000 .000 & 162.767 .410 \\
\hline
\end{tabular}

As seen in table 3 the profit of the business is $10,33 \%$ of sales revenue average. In the other hand, in a normal condition the average profit is $13,22 \%$. Based on setting price, found that profit variable contribution margin (PVCM) for each item offer is varies and not all item give profit. Table 4 shows the PVCM per item menu offer. Base on this calculation, warteg business is attractive, it promises good profit in all perspectives although few menus give loss. Table 4 shows that the highest PVCM is orange juice $70,20 \%$ and the lowest one is mackerel $10,31 \%$. Furthermore, Crispy tempeh as the cheapest menu only give PVCM as much as $-124,70 \%$, in other word, it does not give anything to business but for the owner, it loss covered by other menu which give totally $615,19 \%$ of PVCM.

Based on the calculatin, it is understandable why most of people choose culinary business, either the interesting profit or market size, culinary business becoming promising business in every economic situation. Of course, buying franchise license help the potential investor easy in open 
the business, but profit simulation not always give accurate calculation. Whether choosing established warteg with selfforce or franchise system are depend on the person. Both of system have advantage and disadvantage. Advantage of start warteg business with self-force are determine the initial investment according to owner ability, can improve the taste food, design the interior as owner taste, flexible open time, While the disadvantage is determining different name as competitor, have to calculate all the cost by themselves, train the employee, need full attention on branding process, production process and sales process. In the other hand, choosing start warteg with franchise system give advantage such as supply readiness, skilled the cook, standard taste and menu. Furthermore, start warteg with franchise system helps the business owner to run the business likes expert.

If we compare the initial cost opening warteg using self-force and franchising system, it will be most costly using franchising system. While from the operational aspect, franchising gives the business owner easier than self-force. Based on the pricing flexibilities, self-force gives additional advantages. Furthermore, business profit of warteg also give 10\% to $13 \%$ average every year and income up to hundreds of millions a year.

\section{Table 4. Warteg Menu's Profitable Variable Contribution Margin}

\begin{tabular}{clrrlr}
\hline No. & \multicolumn{1}{c}{ Menu } & PVCM & No. & \multicolumn{1}{c}{ Menu } & PVCM \\
\hline 1. & Rice & $57,80 \%$ & 14. & Fried eggs & $59,70 \%$ \\
2. & Soup & $26,54 \%$ & 15. & Omelette & $42,72 \%$ \\
3. & Jackfruit & $13,36 \%$ & 16. & Mackerel & $10,31 \%$ \\
& Vegetable & & & & \\
4. & Capcay & $27,96 \%$ & 17. & Tilapia fish & $20,30 \%$ \\
5. & Snap Vegetable & $26,54 \%$ & 18. & Pomfret & $14,22 \%$ \\
6. & Bean & $30,94 \%$ & 19. & Milkfish & $27,13 \%$ \\
& Vegetable & & & & \\
7. & Anchovy & $67,58 \%$ & 20. & Fried cob & $43,61 \%$ \\
8. & Rebon shrimp & $25,86 \%$ & 21. & Cue Fish & $28,78 \%$ \\
9. & Tempeh Oreg & $32,02 \%$ & 22. & Tofu Stew & $10,15 \%$ \\
10. & Fried chicken & $38,02 \%$ & 23. & Fried & $-10,60 \%$ \\
& & & Bakwan & \\
11. & Chicken & $-1,54 \%$ & 24. & Crispy & $-124,70 \%$ \\
& Gizzard & & & Tempeh & \\
\hline 12. & Balado Eggs & $32,52 \%$ & 25. & Sweet iced & $51,33 \%$ \\
& & & tea & \\
\hline 13. & Chicken & $-5,56 \%$ & 26. & Orange & $70,20 \%$ \\
& Rendang & & & juice & \\
\hline
\end{tabular}

\section{CONCLUSION}

Based on the research, we can conclude that starting warteg business is interesting since it related to human needs and give stable income and profit, either started by self-force or franchise system.

\section{REFERENCES}

Calkins, Tim. (2019). Kellog On Branding: in a hyperConnected World. John Wiley \& Sons, Inc. New Jersey

Gillis, W. E., Combs, J. G., \& Yin, X. (2020). Franchise management capabilities and franchisor performance under alternative franchise ownership strategies. Journal of Business Venturing, 35(1), 105899.

Kadarisman, Muh. (2019). The influence of government and MUI mediation towards marketing strategy of Warteg and its impact on developing MSMEs in Jakarta, Indonesia, Cogent Business \& Management, Vol. 6 No. 1. Page 1-22

Kelepouris, C. (2019). The Strategic or Not-So Strategic Evolution of Franchise Ownership Patterns-a Study of Optimal Proportions. Temple University. ProQuest Dissertations Publishing retrieved from https://scholarshare.temple.edu/bitstream/ handle/20.500.12613/3094/TETDEDXKelepouristemple-0225E-13660.pdf? sequence $=1 \&$ isAllowed $=y$ access on 25 July 2021

Kotler, P. dan Amstrong, G, (2017). Principles of Marketing. $17^{\text {th }}$ Edition., Pearson Education Limited. England

Kotler, P. dan Keller, L.K. (2016). Marketing Management. $15^{\text {th }}$ Edition, Pearson Education Limited. England

Liczmańska-Kopcewicz, K.(2019) The image transfer in franchise system: The conceptual approach. Marketing i Rynek, No. 05 pages 13-20

Meilasari-Sugiana, Astrid; Susanto, Tri; Novianti, Mirsa. (2019). Jakarta's WARTEG food stall phenomenon: Constraints and opportunities for integration. Human Geographies; Bucharest Vol. 13, Iss. 2, page 187-207.

Porter, M.E. (1998). Competitive Strategy Tehniques for Analyzing Industries and Competitors. The Free Press. New York

Ramdhan, H. E. (2010). Jitu Membeli: Franchise. PT Niaga Swadaya.

Seid, M. H., \& Mazero, J. (2017). Franchise management for dummies. John Wiley \& Sons.

Shumba, K., \& Zindiye, S. (2018). Success factors of franchise entrepreneurs operating in a volatile business environment: A case of the fast food industry Harare, Zimbabwe. The Social Sciences, 13(4), 908-991.

Tampubolon, L. H. (2020). Warung Tegal: Business Unit based on Etnicity. In Proceedings of the 2nd International Conference on Inclusive Business in the Changing World (ICIB 2019), pages 263-267

Tjiptono, F dan Chandra, G. (2018). Pemasaran Strategik. $3^{\text {rd }}$ Edition, Andi Offset. Yogyakarta

Wirtz, J. dan Loevelock, C, (2016). Service Marketing. $8^{\text {th }}$ edition. WorldScientific. USA

Wulandari, R., \& Herlina, M. G. (2021). Application of Strategic Entrepreneurship Approach in Franchise 
and Non-franchise Business: A Study in NonFormal English Education in Indonesia. Journal of Business and Behavioural Entrepreneurship, 5(1), 127-141.

https://www.franchoice.com/wp-content/ uploads/2017/04/History-of-Franchising.pdf accessed on 25 July 2021

https://wartegkharismabaharigroup.com/about-us accessed on 25 July 2021 https://travel.kompas.com/read/2019/11/21/120000727/ tertarik-berbisnis-warteg-modern-ini-biaya-modalfranchise-yang-dibutuhkan?page=all

https://money.kompas.com/read/2019/03/24/121200826/ inspirasi-usaha--warjak-jadi-juragan-warung-nasitanpa-repot?page $=$ all

http://amp.tirto.id/120-ribu -pekerja-industri-hiburankehilangan-kerja-karena-covid-19-eGcC 